\title{
Modeling and Assessment of a Biomass Gasification Integrated System for Multigeneration Purpose
}

\author{
Shoaib Khanmohammadi, Kazem Atashkari, and Ramin Kouhikamali \\ Department of Mechanical Engineering, Faculty of Engineering, University of Guilan, P.O. Box 3756, Rasht, Iran \\ Correspondence should be addressed to Kazem Atashkari; atashkar@guilan.ac.ir
}

Received 31 October 2015; Accepted 6 January 2016

Academic Editor: Ahmadreza Ghaffarizadeh

Copyright ( 2016 Shoaib Khanmohammadi et al. This is an open access article distributed under the Creative Commons Attribution License, which permits unrestricted use, distribution, and reproduction in any medium, provided the original work is properly cited.

\begin{abstract}
The use of biomass due to the reduction in greenhouse gas emissions and environmental impacts has attracted many researchers' attention in the recent years. Access to an energy conversion system which is able to have the optimum performance for applying valuable low heating value fuels has been considered by many practitioners and scholars. This paper focuses on the accurate modeling of biomass gasification process and the optimal design of a multigeneration system (heating, cooling, electrical power, and hydrogen as energy carrier) to take the advantage of this clean energy. In the process of gasification modeling, a thermodynamic equilibrium model based on Gibbs energy minimization is used. Also, in the present study, a detailed parametric analysis of multigeneration system for undersigning the behavior of objective functions with changing design parameters and obtaining the optimal design parameters of the system is done as well. The results show that with exergy efficiency as an objective function this parameter can increase from $19.6 \%$ in base case to $21.89 \%$ in the optimized case. Also, for the total cost rate of system as an objective function it can decrease from $154.4 \$ / \mathrm{h}$ to $145.1 \$ / \mathrm{h}$.
\end{abstract}

\section{Introduction}

One important issue which has attracted the attention of researchers in the recent years is the environmental problems and use of renewable energy sources to mitigate the global warming effects in energy conversion systems. The use of biomass as a clean fuel with organism sources as a suitable fuel with high conversion efficiency has been considered by many researchers.

Reducing fossil fuels dependency by utilizing new energies such as biomass is possible. The use of renewable fuels can significantly help reduce the effects of greenhouse gases and global warming phenomenon. A multigeneration system can generate some output products using one or more input energy. The main objectives of a multigeneration system include increase in efficiency, reduction in the environmental impacts, and reduction in final cost rate of products. In recent years, some studies have been done on trigeneration systems as a type of multigeneration and the use of renewable energies as the prime mover of such systems.
Li et al. [1] carried out a thermal-economic optimization for a distributed multigeneration energy system. They find the optimum system configuration, design, and operation under different economic and environmental legislation.

Al-Sulaiman et al. [2] modeled a trigeneration system including an Organic Rankine Cycle, a single effect absorption chiller, and a biomass burning unit and carried out an exergy and exergoeconomic analysis for the proposed system. The analysis of the system showed that biomass burner with 55\% exergy destruction rate and organic Rankine Cycle evaporator with $38 \%$ have the maximum exergy destruction rate in the system. Chicco and Mancarella [3] investigated polygeneration system from thermodynamic and environmental impact point of view. In another study, Huang et al. [4] examined key, technical, and economic characteristics of a system combined with Organic Rankine Cycle and direct combustion of biomass. This study was performed for ash content of biomass from $0.57 \%$ to $14.26 \%$ and moisture content of 10.6. The results showed that, in the pure electric generation mode, maximum efficiency and final cost rate are $221 \mathfrak{k} / \mathrm{kWh}$ and $11.1 \%$, respectively. Also, for cogeneration heat 


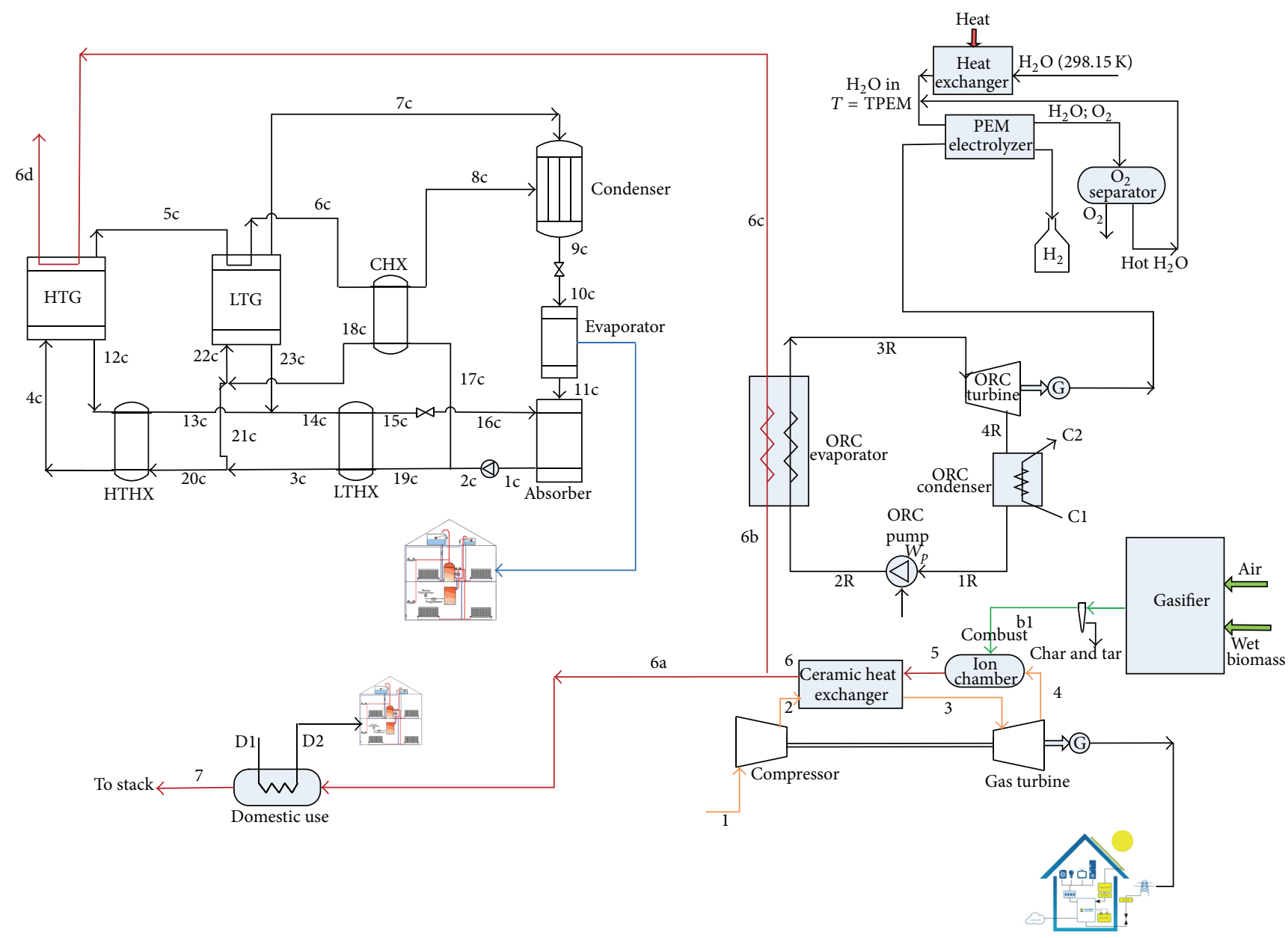

FIGURE 1: Schematic diagram of multigeneration system.

and power, maximum efficiency and cost rate were $87 £ / \mathrm{kWh}$ and $85 \%$, and for trigeneration, maximum efficiency and cost rate were $103 \mathfrak{E} / \mathrm{kWh}$ and $71.7 \%$, respectively.

Rubio-Maya et al. [5] proposed a procedure based on the superstructure definition containing possible configurations of polygeneration system to produce electricity, heat, cool, and fresh water. They used an optimization procedure which included three important criteria, namely, energy saving aspects, greenhouse gas (GHG) emission, and economic factors. Hosseini et al. [6] investigated an integrated solid oxide fuel cell and a microgas turbine for desalination purposes. The results showed that the fuel cell stack pressure has a significant effect on the hybrid system and increase in the stack pressure increases the output power and fresh water capacity. Huang et al. [7] in their study examined a system with biomass feed for a number of residential buildings. In this study, a downdraft gasifier and different type of biomasses were used. They concluded that trigeneration system with heat to power ratio of 0.5 is suitable in residential buildings application. Furthermore, specific investment costs show that trigeneration system with biomass fuel for small units ranges from $2520 £ / \mathrm{kWh}$ to $2579 £ / \mathrm{kWh}$. As the literature review shows, there is a gap in the multiobjective optimization of multigeneration systems integrated with biomass gasification. The present study attempts to give a precise model of biomass gasification process using a thermodynamic equilibrium model based on Gibbs free energy minimization. Also, this exact model is used in a multigeneration system for cooling, heating, electric power generation, and hydrogen energy as an energy carrier. To obtain the optimum design parameters, an optimization procedure based on defined objectives is performed.

\section{System Description}

Figure 1 shows a schematic of the multigeneration system integrated with biomass gasification. The system consists of a gas turbine to be launched by hot air. A gasifier produces syngas using gasification of dry biomass. Produced syngas is combined with air exiting the gas turbine and generates combustion products at $1450 \mathrm{~K}$ in combustion chamber. Part of the combustion products after passing through ceramic heat exchanger enters an organic evaporator to run an Organic Rankin Cycle and after that by entering a double 
TABLE 1: Thermodynamic properties of modeled system.

\begin{tabular}{lcccc}
\hline Point & $\begin{array}{c}\text { Mass flow } \\
\text { rate }(\mathrm{kg} / \mathrm{s})\end{array}$ & $\begin{array}{c}\text { Pressure } \\
(\mathrm{kPa})\end{array}$ & $\begin{array}{c}\text { Temperature } \\
(\mathrm{K})\end{array}$ & $\begin{array}{c}\text { Enthalpy } \\
(\mathrm{kJ} / \mathrm{kg})\end{array}$ \\
\hline 1 & 6.689 & 100 & 298.2 & 305.8 \\
2 & 6.689 & 911.9 & 601 & 623.3 \\
3 & 6.689 & 884.5 & 1250 & 1370 \\
4 & 6.689 & 101.8 & 667.2 & 785.4 \\
5 & 8.581 & 106.63 & 1400 & 1614 \\
6 & 8.581 & 101.3 & 940.3 & 1032 \\
6a & 1.716 & 101.3 & 940.3 & 1032 \\
6b & 6.865 & 101.3 & 940.3 & 1032 \\
6c & 6.865 & 101.3 & 400 & 414.3 \\
6d & 6.865 & 101.3 & 373 & 385.5 \\
7 & 1.716 & 101.3 & 400 & 414.3 \\
1R & 20.08 & 130.7 & 308 & 236.6 \\
2R & 20.08 & 1000 & 308.4 & 237.7 \\
3R & 20.08 & 1000 & 384.1 & 448.4 \\
4R & 20.08 & 130.7 & 326.4 & 417.6 \\
D1 & 42.23 & 200 & 308 & 146.6 \\
D2 & 42.23 & 200 & 338 & 272.1 \\
\hline
\end{tabular}

effect absorption chiller discharge to environment. Remaining combustion products enter into a heat exchanger with a lower temperature for generation of hot water and finally will be released in environment at $110^{\circ} \mathrm{C}$. A proton exchange membrane (PEM) uses a part of electrical output of ORC to produce hydrogen as an energy carrier.

Table 1 shows some thermodynamic properties of multigeneration system.

\section{Modeling}

\subsection{Thermodynamic Modeling}

3.1.1. Gasifier. Thermodynamic equilibrium equations have been used for modeling the gasification process which take place in the gasifier. The general form of chemical reaction in the gas producer is assumed as [13]

$$
\begin{gathered}
\mathrm{CH}_{x} \mathrm{O}_{y} \mathrm{~N}_{z}+w \mathrm{H}_{2} \mathrm{O}+m\left(\mathrm{O}_{2}+3.76 \mathrm{~N}_{2}\right) \longrightarrow \\
x_{1} \mathrm{H}_{2}+x_{2} \mathrm{CO}+x_{3} \mathrm{H}_{2} \mathrm{O}+x_{4} \mathrm{CO}_{2}+x_{5} \mathrm{CH}_{4}+x_{6} \mathrm{~N}_{2}
\end{gathered}
$$

Here, $\mathrm{CH}_{x} \mathrm{O}_{y} \mathrm{~N}_{z}$ indicate the biomass chemical formula and $w$ is the amount of water per kmol of biomass. All coefficients $x_{1}$ to $x_{6}$ can be obtained from atomic balance and using equilibrium constant equations. The procedure can be expressed as

$$
\begin{aligned}
x_{2}+x_{4}+x_{5} & =1, \\
2 x_{1}+2 x_{3}+4 x_{5} & =x+2 w, \\
x_{2}+x_{3}+2 x_{4} & =y+w+2 m, \\
x_{2}+x_{3}+2 x_{4} & =y+2 m+w .
\end{aligned}
$$

The other equations can be obtained from equilibrium reaction. As it is expected pyrolysis products before reaching reduction region are fired and prior to emitting from gasifier achieve equilibrium state; the reactions can be written as follows:

$$
\begin{aligned}
& \mathrm{C}+\mathrm{CO}_{2} \longrightarrow 2 \mathrm{CO} \\
& \mathrm{C}+\mathrm{H}_{2} \mathrm{O} \longrightarrow \mathrm{CO}+\mathrm{H}_{2}
\end{aligned}
$$

Zainal et al. [12] and Higman and Van der Burgt [14] showed that (3) and (4) can be combined to give the water-gas shift reaction as follows:

$$
\mathrm{CO}+\mathrm{H}_{2} \mathrm{O} \longrightarrow \mathrm{CO}_{2}+\mathrm{H}_{2}
$$

Another equilibrium reaction is methane reaction, which can be expressed as

$$
\mathrm{C}+2 \mathrm{H}_{2} \longrightarrow \mathrm{CH}_{4}
$$

The equilibrium constants for water-gas shift reaction and methane reaction can be written as follows [11]:

$$
\begin{aligned}
& K_{1}=\frac{x_{1} x_{4}}{x_{2} x_{3}}, \\
& K_{2}=\frac{x_{5}}{x_{1}^{2}} n_{\text {total }} .
\end{aligned}
$$

The equilibrium constant can be obtained using Gibbs function change for each reaction as [8]

$$
\begin{aligned}
& \ln K=-\frac{\Delta G_{T}^{\circ}}{\bar{R} T}, \\
& \Delta G_{T}^{\circ}=\sum_{i} v_{i} \Delta \bar{g}_{f, T, i}^{\circ} .
\end{aligned}
$$

Here, $\Delta G_{T}^{\circ}$ is the standard Gibbs free energy of reaction, and $\Delta \bar{g}_{f, T, i}^{\circ}$ shows the standard Gibbs function of formation at the given temperature $T$ for the gas species $i$ and $\bar{R}$ is the universal gas constant, $8.314 \mathrm{~kJ} /(\mathrm{kmol} \cdot \mathrm{K})$. Finally, an energy balance is utilized to evaluate the gasification temperature $\left(T_{g}\right)$ as follows [8]:

$$
\begin{aligned}
\vec{h}_{f, \text { biomass }}^{\circ}+w \bar{h}_{f, \mathrm{H}_{2} \mathrm{O}}^{\circ}= & x_{1}\left(\bar{h}_{f, \mathrm{H}_{2}}^{\circ}+\Delta \bar{h}\right) \\
& +x_{2}\left(\bar{h}_{f, \mathrm{CO}}^{\circ}+\Delta \bar{h}\right) \\
& +x_{3}\left(\bar{h}_{f, \mathrm{H}_{2} \mathrm{O}}^{\circ}+\Delta \bar{h}\right) \\
& +x_{4}\left(\bar{h}_{f, \mathrm{CO}_{2}}^{\circ}+\Delta \bar{h}\right) \\
& +x_{5}\left(\bar{h}_{f, \mathrm{CH}_{4}}^{\circ}+\Delta \bar{h}\right) \\
& +x_{6}\left(\bar{h}_{f, \mathrm{~N}_{2}}^{\circ}+\Delta \bar{h}\right) .
\end{aligned}
$$

$\bar{h}_{f}^{\circ}$ is the formation enthalpy in terms of $\mathrm{kJ} / \mathrm{kmol}$, and $\Delta \bar{h}^{\circ}$ is enthalpy difference for the given state with reference state. $\vec{h}_{f}$ 
is the enthalpies of the formation of the biomass, moisture, hydrogen, carbon monoxide, water, carbon dioxide, methane, and nitrogen, respectively. To calculate LHV, the experimental relation used by Channiwala and Parikh [15] has been used:

$$
\begin{aligned}
\mathrm{HHV}= & 0.3491 \mathrm{C}+1.1783 \mathrm{H}+0.1005 \mathrm{~S}-0.1034 \mathrm{O} \\
& -0.0151 \mathrm{~N}-0.0211 \mathrm{Ash}, \\
\mathrm{LHV}= & \mathrm{HHV}-9 m_{\mathrm{H}} h_{f g} .
\end{aligned}
$$

The coefficients ASH, N, O, S, and $\mathrm{H}$ are the weight percent of the components of solid fuel, $m_{\mathrm{H}}$ is the weight percent of hydrogen in fuel, and $h_{f g}$ is the water vapor enthalpy.

3.1.2. Organic Rankine Cycle. As it can be seen in Figure 1, the combustion products enter the Organic Rankine Cycle evaporator at $6 \mathrm{~b}$ point and launch this cycle. The governing equations of the Organic Rankine Cycle at steady state condition are mass balance and energy balance; more detail can be found in [16].

3.1.3. Proton Exchange Membrane (PEM) Electrolyzer. In this research hydrogen is used as our energy carrier. Thus, a PEM electrolyzer for hydrogen production is used. The electricity and heat are fed to the electrolyzer to drive the electrochemical reactions in PEM electrolyzer. As shown in Figure 1, liquid water at ambient temperature enters a heat exchanger that heats it to the PEM electrolyzer temperature before it enters the electrolyzer. Leaving the cathode at the reference temperature, the hydrogen produced is stored in a storage tank. The oxygen gas produced at the anode is separated from the water and oxygen mixture and then cooled to the reference environment temperature. The remaining water is returned to the water supply stream for the next hydrogen production cycle. The overall PEM electrolysis reaction is water splitting; that is, electricity and heat are used to separate water into hydrogen and oxygen.
The mass flow rate of hydrogen produced from PEM electrolyzer can be calculated as

$$
\dot{m}_{\mathrm{H}_{2}}=\eta_{\text {elec }} \frac{\dot{W}_{\text {net,ORC }}}{\mathrm{HHV}_{\mathrm{H}_{2}}} .
$$

Here $\eta_{\text {elec }}$ is efficiency of the electrolyzer which is about $60 \%$ and $\mathrm{HHV}_{\mathrm{H}_{2}}$ is the higher heating value of hydrogen which is $142.19 \times 10^{6} \mathrm{~J} / \mathrm{kg}$. The exergy of hydrogen stream can be calculated as

$$
\mathrm{ex}_{\mathrm{H}_{2}}=\mathrm{ex}_{\mathrm{ph}, \mathrm{H}_{2}}+\mathrm{ex}_{\mathrm{ch}, \mathrm{H}_{2}} \text {. }
$$

The physical and chemical exergy of hydrogen are given as [17]

$$
\begin{aligned}
\operatorname{ex}_{\mathrm{ph}, \mathrm{H}_{2}} & =\left(h_{\mathrm{H}_{2}}-h_{\circ, \mathrm{H}_{2}}\right)-T_{\mathrm{o}}\left(s_{\mathrm{H}_{2}}-s_{\circ, \mathrm{H}_{2}}\right), \\
\operatorname{ex}_{\mathrm{ch}, \mathrm{H}_{2}} & =\frac{253153}{\mathrm{MW}_{\mathrm{H}_{2}}} .
\end{aligned}
$$

More details about thermochemical modeling of the PEM electrolyzer are given elsewhere [18].

3.1.4. Gas Turbine. The governing equation on the gas turbine cycle that is used for the thermodynamic modeling of the system components is as follows:

$$
\begin{aligned}
\dot{W}_{\mathrm{GT}} & =\dot{m}_{3}\left(h_{3}-h_{4}\right), \\
\eta_{\text {Eva,organic }} & =\frac{\dot{m}_{5}\left(h_{5}-h_{6}\right)}{\dot{m}_{2}\left(h_{3}-h_{2}\right)}, \\
\eta_{\text {is,comp }} & =\frac{h_{2 s}-h_{1}}{h_{2}-h_{1}}, \\
\dot{m}_{4} h_{4}+\dot{m}_{b_{1}} h_{b_{1}} & =\dot{m}_{5} h_{5} .
\end{aligned}
$$

To calculate the chemical exergy of the fuel, lower heating value and the coefficient $\beta$ are required and written as follows $[19,20]:$

$$
\begin{aligned}
\operatorname{ex}_{\text {biomass }} & =\beta \mathrm{LHV}_{\text {wood }}, \\
\operatorname{HHV}(\mathrm{kJ} / \mathrm{kg}) & =349.1 \mathrm{C}+1178.3 \mathrm{H}+100.5 \mathrm{~S}-103.4 \mathrm{O}-15.1 \mathrm{~N}-21.1 \mathrm{ASH}, \\
\beta & =\frac{1.044+016\left(Z_{\mathrm{H}} / Z_{\mathrm{C}}\right)-.34493\left(Z_{\mathrm{O}} / Z_{\mathrm{C}}\right)\left(1+.0531\left(Z_{\mathrm{H}} / Z_{\mathrm{C}}\right)\right)}{1-0.4124\left(Z_{\mathrm{O}} / Z_{\mathrm{C}}\right)} .
\end{aligned}
$$

$Z_{\mathrm{O}}, Z_{\mathrm{H}}$, and $Z_{\mathrm{C}}$ are the mass components of carbon, hydrogen, oxygen, and nitrogen in biomass. For the studied biomass with the presented chemical formula and the above equation, the higher heating value of fuel is $19980 \mathrm{~kJ} / \mathrm{kg}$. Also, the lower heating value of the biomass can be calculated by the following equation and given that $h_{f g}=2258 \mathrm{~kJ} / \mathrm{kg}$ [20]:

$$
\operatorname{LHV}(\mathrm{kJ} / \mathrm{kg})=\mathrm{HHV}-h_{f g}\left(\frac{9 \mathrm{H}}{100}+\frac{\mathrm{M}}{100}\right)
$$

In the above equation, $\mathrm{H}$ and $\mathrm{M}$ are the percent of hydrogen and moisture content, respectively.

3.1.5. Double Effect Absorption Chiller. This type of chiller can be used for ventilation and cooling purposes. Compared to the compressed cooling system, this system requires less shaft work for cooling generation. Water-ammonium is a widely used working fluid and is used in absorption systems and multigeneration objectives. In the system analysis, the 
mass conservation law and energy balance are used for each component of double effect absorption chiller as a control volume. The law of conservation of mass for the overall mass and component conservation for each component of the solution in a steady mode and constant current is written as follows:

$$
\begin{aligned}
\sum \dot{m}_{i} & =\sum \dot{m}_{o}, \\
\sum(\dot{m} x)_{i} & =\sum(\dot{m} x)_{o} .
\end{aligned}
$$

Here, $\dot{m}$ is the mass flow rate of working fluid and $x$ is the concentration of ammonium in the solution. The energy equilibrium for the system components is written as follows [21]:

$$
\dot{Q}-\dot{W}=\sum_{o} \dot{m}_{o} h_{o}-\sum_{i} \dot{m}_{i} h_{i}
$$

(a) Exergy Analysis. To obtain the exergy of each point of the cycle, by considering the control volume for each component in the steady state, the exergy balance equation is as follows:

$$
\sum_{i} \dot{m}_{i} \mathrm{ex}_{i}=\sum_{o} \dot{m}_{o} \mathrm{ex}_{o}+\dot{I}
$$

The exergy of different points is composed of two parts including physical exergy and chemical exergy:

$$
\mathrm{ex}=\mathrm{ex}_{\mathrm{ph}}+\mathrm{ex}_{\mathrm{ch}} \text {. }
$$

The chemical exergy of each state depends on its pressure and temperature that is shown as follows:

$$
\mathrm{ex}_{\mathrm{ph}}=\left(h-h_{\mathrm{o}}\right)-T_{\mathrm{o}}\left(s-s_{\mathrm{o}}\right)
$$

In general, the chemical exergy for a gas mixture can be obtained by the following equation:

$$
\mathrm{ex}_{\mathrm{ch}}=\sum_{i} x_{i} \mathrm{ex}_{o, i}^{\mathrm{ch}}+\bar{R} T_{\circ} \sum_{i} x_{i} \ln x_{i}
$$

where $x_{i}$ is the molar fraction of the $i$ th component and $\mathrm{ex}_{o, i}^{\mathrm{ch}}$ is the standard exergy of the $i$ th pure material. In the absorption chiller, as ammonium water solution is not ideal, the following equation is used for calculating the chemical exergy:

$$
\overline{\mathrm{ex}}_{\mathrm{ch}}=\left(\frac{1}{\bar{M}_{\mathrm{sol}}}\right)\left[\sum_{i=1}^{n} y_{i} \overline{\operatorname{ex}}_{\mathrm{ch}}^{k}+\bar{R} T_{\circ} \sum_{i=1}^{n} y_{i} \ln \left(a_{i}\right)\right] .
$$

With the extension of the above equation for the ammonium water solution, the following can be written:

$$
\begin{aligned}
& \overline{\mathrm{ex}}_{\mathrm{ch}} \\
& =\left(\frac{1}{\overline{\bar{M}}_{\mathrm{sol}}}\right)\left[\begin{array}{c}
y_{\mathrm{H}_{2} \mathrm{O}} \overline{\mathrm{ex}}_{\mathrm{H}_{2} \mathrm{O}}^{\circ}+y_{\mathrm{NH}_{3}} \overline{\operatorname{ex}}_{\mathrm{NH}_{3}}^{\circ}+\bar{R} T_{\circ} \\
\left(y_{\mathrm{H}_{2} \mathrm{O}} \ln \left(a_{\mathrm{H}_{2} \mathrm{O}}\right)+y_{\mathrm{NH}_{3}} \ln \left(a_{\mathrm{NH}_{3}}\right)\right)
\end{array}\right],
\end{aligned}
$$

where $a_{\mathrm{H}_{2} \mathrm{O}}$ is water activity and is the ratio of water vapor pressure in the mixture to pure water pressure and
$a_{\mathrm{NH}_{3}}$ is ammonium activity which is considered as ratio of ammonium vapor pressure in the mixture to pure water pressure. This equation is composed of two parts: the standard chemical exergy of the pure material and the exergy caused by separation process as follows:

$$
\begin{aligned}
\overline{\mathrm{ex}}_{\mathrm{ch}}^{\circ} & =\left(\frac{1}{\bar{M}_{\mathrm{sol}}}\right)\left[y_{\mathrm{H}_{2} \mathrm{O}} \overline{\mathrm{ex}}_{\mathrm{H}_{2} \mathrm{O}}^{\circ}+y_{\mathrm{NH}_{3}}{\left.\overline{\mathrm{ex}_{\mathrm{NH}_{3}}^{\circ}}\right],}_{\overline{\mathrm{ex}}_{\mathrm{ch}}^{\mathrm{dis}}}=\left(\frac{1}{\bar{M}_{\mathrm{sol}}}\right)\left[y_{\mathrm{H}_{2} \mathrm{O}} \ln \left(a_{\mathrm{H}_{2} \mathrm{O}}\right)+y_{\mathrm{NH}_{3}} \ln \left(a_{\mathrm{NH}_{3}}\right)\right],\right.
\end{aligned}
$$

where $y_{i}$ as a molar fraction is as follows:

$$
\begin{aligned}
& y_{\mathrm{H}_{2} \mathrm{O}}=\frac{\left(1-x_{1 w}\right) \bar{M}_{\mathrm{NH}_{3}}}{\left(1-x_{1 w}\right) \bar{M}_{\mathrm{NH}_{3}}+x_{1 w} \bar{M}_{\mathrm{H}_{2} \mathrm{O}}}, \\
& y_{\mathrm{NH}_{3}}=1-y_{\mathrm{H}_{2} \mathrm{O}} .
\end{aligned}
$$

And $x_{1 w}$ is defined as follows:

$$
x_{1 w}=\frac{x_{\mathrm{NH}_{3}}}{100}
$$

where $x_{\mathrm{NH}_{3}}$ is the concentration of ammonium water concentration in a percent form and $\bar{M}_{\mathrm{NH}_{3}}$ and $\bar{M}_{\mathrm{H}_{2} \mathrm{O}}$ are $17 \mathrm{~kg} / \mathrm{kmol}$ and $18 \mathrm{~kg} / \mathrm{kmol}$, respectively.

(b) Economic Analysis. The main aim of the economic modeling is to obtain the cost functions of each component and a calculation of the final cost rate of the system. There are various methods for determining purchase equipment cost in terms of the designed parameters. Here, the function is presented by Bejan and Moran [22], Ahmadi [23], and Soltani et al. [24], with some modifications done in accordance with local conditions and interest rate in Iran. Table 2 shows the cost functions for each component of the trigeneration system in terms of design parameters.

(c) System Assessment. To perform an exact evaluation of the system and the impact of the design parameters on thermodynamic and economic performance, the exergy efficiency and the final cost rate are considered as two objective functions. These objective functions are defined as follows:

$$
\begin{aligned}
\psi= & \frac{\dot{\mathrm{Ex}}_{\mathrm{Q} \text {,domestic }}+\dot{\mathrm{E}} \mathrm{x}_{\text {Cooling }}+\dot{W}_{\text {net }}+\dot{m}_{\mathrm{H}_{2}} \mathrm{ex}_{\mathrm{H}_{2}}}{\dot{\mathrm{Ex}}_{\text {biomass }}}, \\
\dot{C}_{\text {total }}= & \dot{Z}_{\text {total }}+\dot{C}_{\text {biomass }}, \\
\dot{Z}_{\text {total }}= & \dot{Z}_{\text {comp }}+\dot{Z}_{\mathrm{GT}}+\dot{Z}_{\mathrm{AP}}+\dot{Z}_{\mathrm{CC}}+\dot{Z}_{\mathrm{DHW}}+\dot{Z}_{\mathrm{Chiller}} \\
& +\dot{Z}_{\mathrm{Pump}, \mathrm{R}}+\dot{Z}_{\mathrm{Eva}, \mathrm{R}}+\dot{Z}_{\mathrm{Tur}, \mathrm{R}}+\dot{Z}_{\mathrm{Cond}, \mathrm{R}} \\
& +\dot{Z}_{\mathrm{PEM}} .
\end{aligned}
$$

In the above equation $\dot{C}_{\text {biomass }}$ is the biomass cost which is obtained from an analysis of local data and wood purchase costs. 
TABLE 2: The cost function for each composition of the multigeneration system in terms of design parameters $[8,9]$.

\begin{tabular}{|c|c|c|}
\hline Component & Cost function & \\
\hline Air compressor & $Z_{\mathrm{AC}}=\left(\frac{C_{11}}{C_{12}-\eta_{\mathrm{sc}}}\right) r_{p} \ln \left(r_{p}\right)$ & $\begin{array}{c}C_{11}=71.1 \$ /\left(\mathrm{kgs}^{-1}\right) \\
C_{12}=0.9\end{array}$ \\
\hline Combustion chamber & $Z_{\mathrm{CC}}=\left(\frac{C_{21} \dot{m}_{a}}{C_{22}-0.98}\right)\left(1+\exp \left(\mathrm{C}_{32} T_{\text {comb }}-C_{24}\right)\right)$ & $\begin{array}{c}C_{21}=46.08, C_{22}=0.995 \\
C_{23}=0.018, C_{24}=26.4\end{array}$ \\
\hline Gas turbine & $Z_{\mathrm{GT}}=\left(\frac{C_{31} \dot{m}_{g}}{C_{32}-\eta_{\mathrm{GT}}}\right) \ln \left(\frac{P_{4}}{P_{3}}\right)\left(1+\exp \left(C_{33} T_{3}-C_{34}\right)\right)$ & $\begin{array}{r}C_{31}=479.34, C_{32}=0.92 \\
C_{33}=0.036, C_{34}=54.4\end{array}$ \\
\hline Air preheater & $Z_{\mathrm{AP}}=C_{41}\left(\frac{\dot{m}_{5}\left(h_{5}-h_{6}\right)}{U \Delta T_{\mathrm{LM}}}\right)^{0.6}$ & $U=6, C_{41}=4122$ \\
\hline Gasifier & $Z_{\text {gasif }}=1600\left(3600 \times \dot{m}_{\text {biomass }}\right)^{0.67}$ & - \\
\hline Domestic hot water & $Z_{\mathrm{DHW}}=0.3 \dot{m}_{\mathrm{DHW}}$ & - \\
\hline ORC evaporator & $Z_{\mathrm{Eva}}=309.14\left(A_{\mathrm{Eva}}\right)^{0.85}$ & - \\
\hline ORC pump & $Z_{\text {Pump }}=200\left(\dot{W}_{\text {Pump }}\right)^{0.65}$ & - \\
\hline ORC turbine & $Z_{\text {Tur }}=4750\left(\dot{W}_{\text {Tur }}\right)^{0.75}$ & - \\
\hline ORC condenser & $Z_{\text {Condnser }}=516.62\left(A_{\text {Condnser }}\right)^{0.6}$ & - \\
\hline Double effect absorption chiller & $Z_{\text {Chiller }}=1144.3\left(\dot{Q}_{\text {Eva }}\right)^{0.67}$ & - \\
\hline PEM electrolyzer & $Z_{\mathrm{PEM}}=1000\left(\dot{W}_{\mathrm{PEM}, \mathrm{in}}\right)$ & - \\
\hline
\end{tabular}

TABLE 3: A comparison of the modeling syngas composition and experimental result.

\begin{tabular}{lcccc}
\hline Composition & The present model & Experimental [10] & $\begin{array}{c}\text { Jarungthammachote and Dutta [11] } \\
\text { MC = 16\% }\end{array}$ & Zainal et al. [12] \\
\hline $\mathrm{H}_{2}$ & 24.52 & 17 & 18.03 & 18.51 \\
$\mathrm{CO}$ & 26.8 & 18.4 & 11.43 & 19.06 \\
$\mathrm{CO}_{2}$ & 11.03 & 10.6 & 0.11 & 0.64 \\
$\mathrm{CH}_{4}$ & 2.43 & 1.3 & 51.92 & 46.68 \\
$\mathrm{~N}_{2}$ & 42 & 52.7 & & 12.01 \\
\hline
\end{tabular}

\section{Result and Discussion}

4.1. Model Validation. Biomass gasification process is the most important part of the thermodynamic modeling of the multigeneration system. To validate the developed thermodynamic equilibrium model, the results are compared to those of other studies. In order to determine the error of the modeling, the root mean square error of syngas compounds with compounds derived from experimental results [10] and also other researchers' modeling [11] is used. Table 3 shows the syngas compounds produced in the present model, experimental results also the work of others.

As it can be seen, there is a reasonable consistency between the present modeling results and the experimental results by Jayah et al. [10]. The maximum deviation from the experimental results is related to methane. The calculations indicate that root mean square error of the experimental results and the present modeling is 6.9. Also, the error of the present modeling results in the work by Jarungthammachote and Dutta [11] is 6.55. Figure 2 shows the mole fraction of each component of syngas.

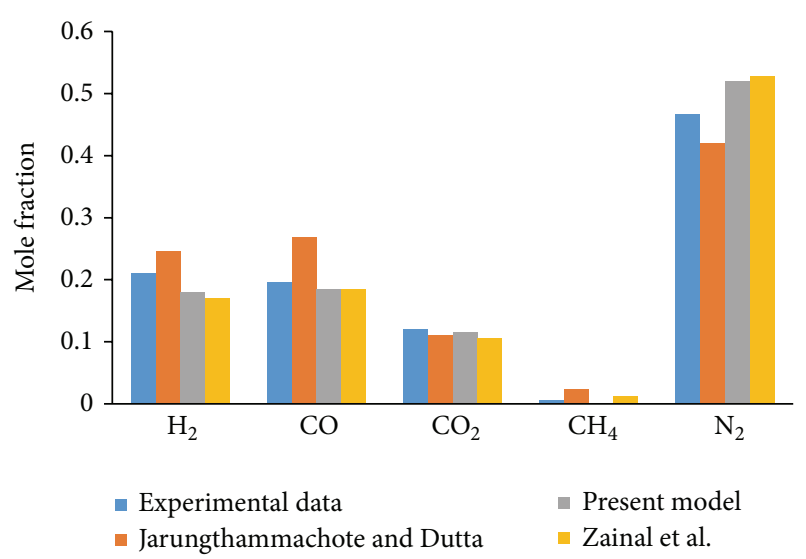

FIGURE 2: Mole fraction of syngas for present and other experimental and numerical studies.

4.2. Exergy Analysis Result. Table 4 presents the different important parameters of multigeneration system under initial operation conditions. The results indicate that the exergy 
TABLE 4: Performance parameters of multigeneration system for the initial state.

\begin{tabular}{lcc}
\hline Parameter & Unit & Value \\
\hline Fuel (biomass) flow rate & $\mathrm{kg} / \mathrm{s}$ & 0.6 \\
Exergy efficiency & $\%$ & 19.69 \\
Energy efficiency & $\%$ & 19.36 \\
Gasification air mass flow rate & $\mathrm{kg} / \mathrm{s}$ & 1.04 \\
Combustion air mass flow rate & $\mathrm{kg} / \mathrm{s}$ & 6.68 \\
ORC turbine output & $\mathrm{kW}$ & 616.6 \\
Gas turbine output & $\mathrm{kW}$ & 1798 \\
Domestic hot water flow rate & $\mathrm{kg} / \mathrm{s}$ & 42.16 \\
Gasifier purchase cost & $\$ / \mathrm{h}$ & 5.9 \\
Compressor purchase cost & $\$ / \mathrm{h}$ & 4.16 \\
Gas turbine cost rate & $\$ / \mathrm{h}$ & 2.08 \\
Heat exchanger cost rate & $\$ / \mathrm{h}$ & 5.14 \\
Combustion chamber cost rate & $\$ / \mathrm{h}$ & 0.47 \\
Domestic water heater cost rate & $\$ / \mathrm{h}$ & 0.22 \\
Organic Rankine Cycle cost rate & $\$ / \mathrm{h}$ & 11.53 \\
Biomass fuel cost & $\$ / \mathrm{GJ}$ & 2 \\
\hline
\end{tabular}

efficiency of multigeneration system is $19.69 \%$. Also, the domestic hot water flow rate in the initial state is $42.16 \mathrm{~kg} / \mathrm{s}$. The economic results show that the ORC unit and gasifier with $11.53 \$ / \mathrm{h}$ and $5.9 \$ / \mathrm{h}$ have the highest cost rate compared with other components.

4.3. Parametric Analysis. In order to determine the effects of the key parameters on the system performance, a parametric study is done. Given that the gasification temperature can significantly impact the percent of the syngas components, to study the impacts of the change in such parameter, its value has changed from $950 \mathrm{~K}$ to $1250 \mathrm{~K}$. Figure 3 shows the range of such changes. As it could be seen, increase in the gasification temperature can reduce both overall system efficiency and costs simultaneously. Given that changes in gasification temperature can directly influence the percent of the generated gases, it can influence the air required for complete combustion in combustion chamber. By an increase in the relevant range, it can be found that the air required for combustion decreases from $7.57 \mathrm{~kg} / \mathrm{s}$ to $5.88 \mathrm{~kg} / \mathrm{s}$.

Figure 4 shows the effect of this parameter on the main output of the system. The results indicate that cooling capacity and hot water output are not sensitive to change the gasification temperature while electricity output of the system decreases with an increment in the gasification temperature. Also, the hydrogen production rate in changing range of gasification temperature experiences an increment and decrement trend. It should be noted that such behavior is due to increment and decrement trend of electrical output of ORC. When the gasification temperature increases, there are two opposite effects.

To investigate the combustion temperature effects on the system performance this parameter is changed from $1300 \mathrm{~K}$ to

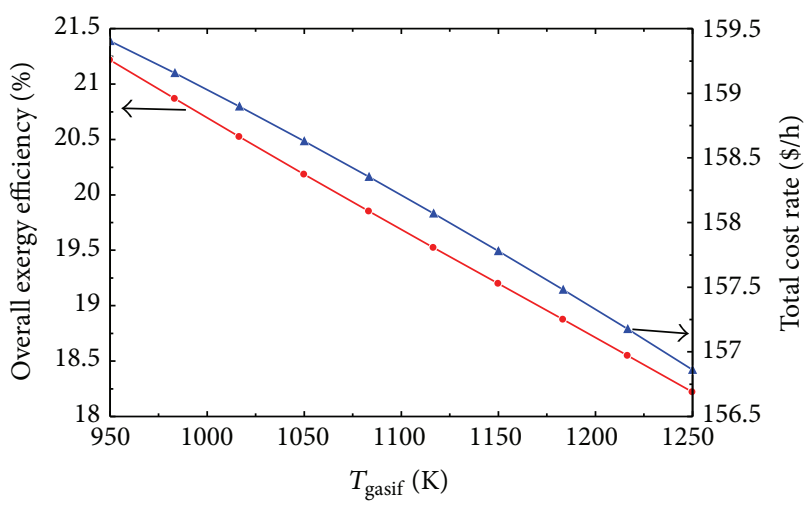

FIGURE 3: The impact of the gasification temperature on the objective functions.

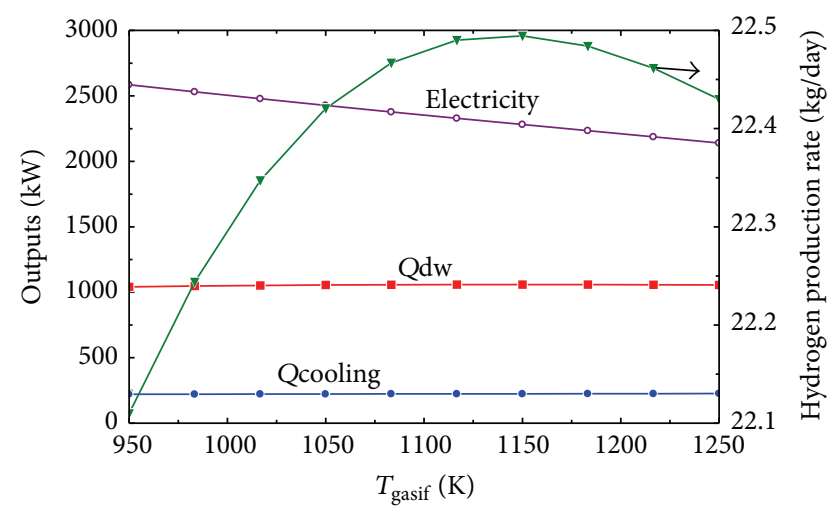

FIgURE 4: The impact of the gasification temperature on the main outputs. Qdw: domestic water heater. Qcooling: absorption chiller output.

$1400 \mathrm{~K}$. It can be seen in the higher combustion temperature that the exergy efficiency of the system and total cost rate of the system experience lower values (Figure 5).

The changing of the main outputs of the system with variation of combustion temperature of syngas is illustrated in Figure 6. As it can be seen the cooling capacity of the system has no change with combustion temperature change, while hydrogen production rate and domestic hot water increase with combustion temperature increment. It can be found that in the reasonable range of combustion temperature the total electricity output decreases from $2534 \mathrm{~kW}$ to $2353 \mathrm{~kW}$. Since the decrement in the electricity output of the system is higher than increment in the exergy of produced hydrogen, the exergy efficiency decreases with raising the combustion temperature.

One of the main parameters effective in the system performance is compressor pressure ratio. The result shows that increase in the compressor pressure ratio leads to energy and exergy efficiency to a limited extent. Figure 7 presents that for the pressure ratio higher than 9.5 the energy efficiency will decrease. Since the higher pressure ratio imposes more work to derive compressor, the exergy and energy efficiency in higher pressure ratio show a decrement. 


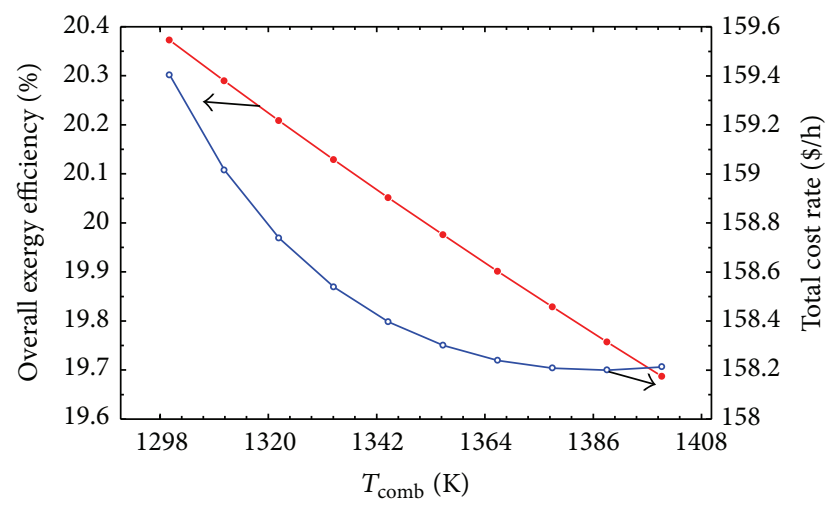

FIgURE 5: The impact of the combustion temperature on the two objective functions.

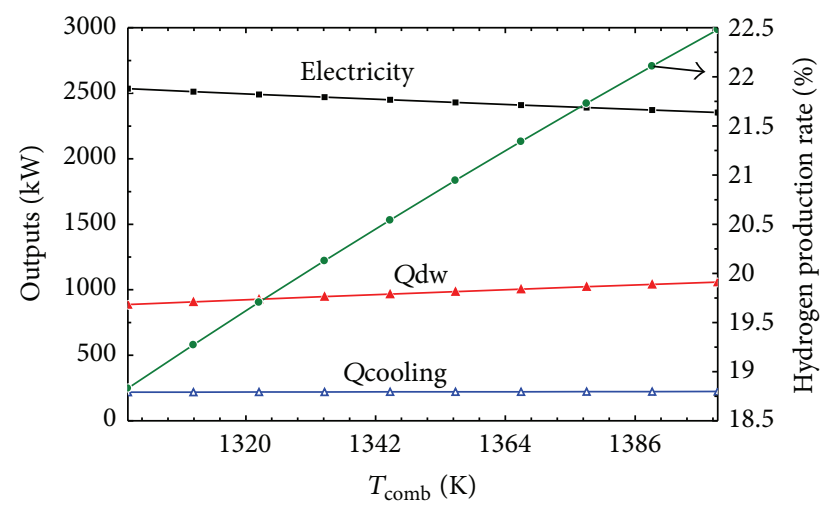

FIGURE 6: The impact of the combustion temperature on the main outputs. Qdw: domestic water heater. Qcooling: absorption chiller output.

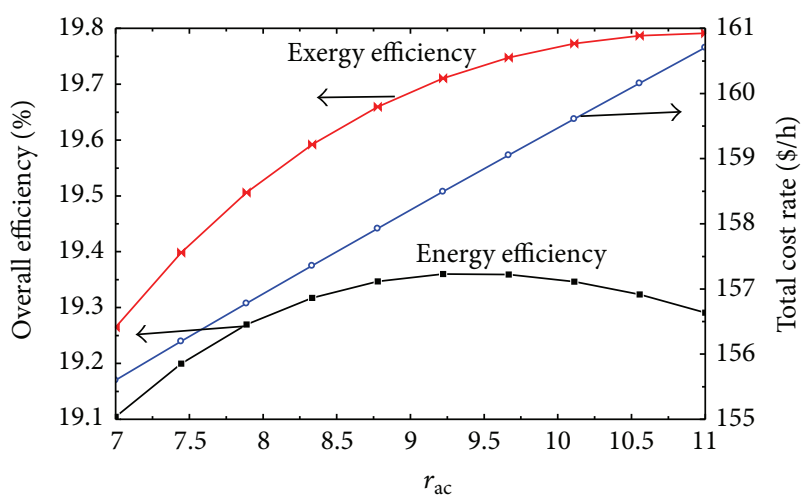

FIGURE 7: The impact of the compressor pressure ratio on the cost rate and efficiencies.

An important parameter which has a severe effect on the ORC performance is the ORC maximum pressure. To examine the influence of this parameter, the maximum pressure in the range of $800 \mathrm{kPa}$ to $2000 \mathrm{kPa}$ has been considered as variable. As it can be seen in Figure 8 an increase in Organic Rankine Cycle pressure simultaneously increases the overall cost of the system, energy efficiency, and exergy efficiency.

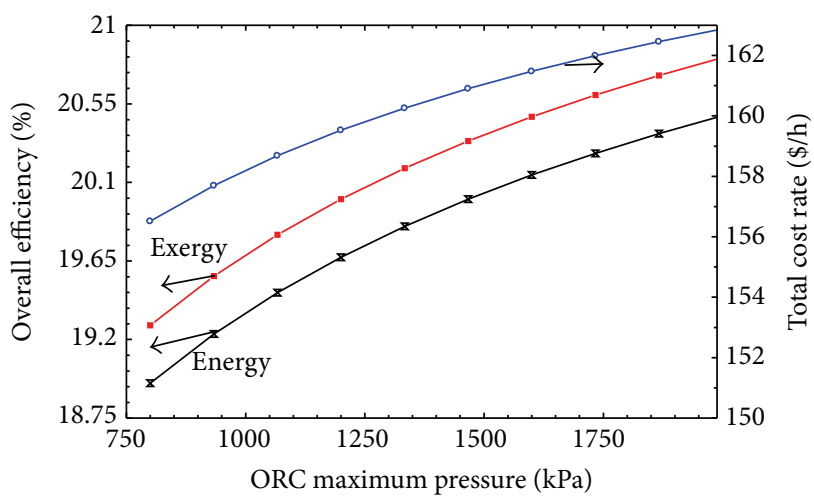

FIGURE 8: The impact of the compressor pressure ratio on the maximum pressure of ORC.

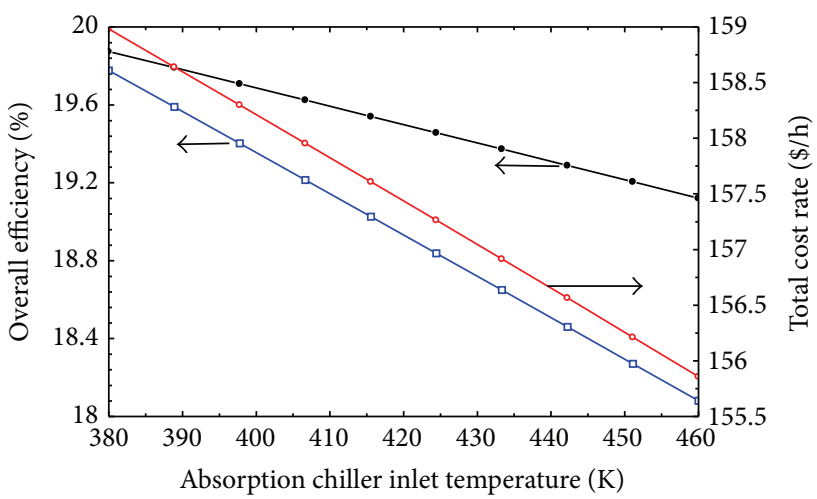

FIGURE 9: The impact of the inlet temperature to chiller on the objective functions.

The higher ORC maximum pressure leads to the higher work output from organic turbine which results in increase in the exergy and energy efficiency of the system. At the higher ORC maximum pressure the cost of the ORC components increases which leads to increase in the total cost rate of the system as it can be seen in Figure 9.

Also, Figure 9 illustrates the effect of changing inlet temperature to the chiller on the total cost rate, energy efficiency, and exergy efficiency. The results exhibit that an increment in the inlet temperature to chiller decreases energy efficiency, exergy efficiency, and total cost rate of the system. Increasing this parameter has two effects on the system. Increasing this temperature could lead to increase in cooling capacity and on the other hand decrease in the ORC power output because of lower energy gain in the ORC evaporator.

Due to the change of molar fraction of syngas composition, the biomass moisture content can significantly impact the system performance. As it could be seen in Figure 10, by increasing the moisture from 0.1 to 0.3 , the system overall cost rate and the second law efficiency are reduced substantially.

The ratio of the mass flow rate for ORC evaporator $\left(\dot{m}_{6 \mathrm{~b}}\right)$ to the mass flow rate of ceramic heat exchanger $\left(\dot{m}_{6}\right)$ is bypass ratio. The result of bypass ratio variation demonstrates that an increment in this parameter results in an increment in the 


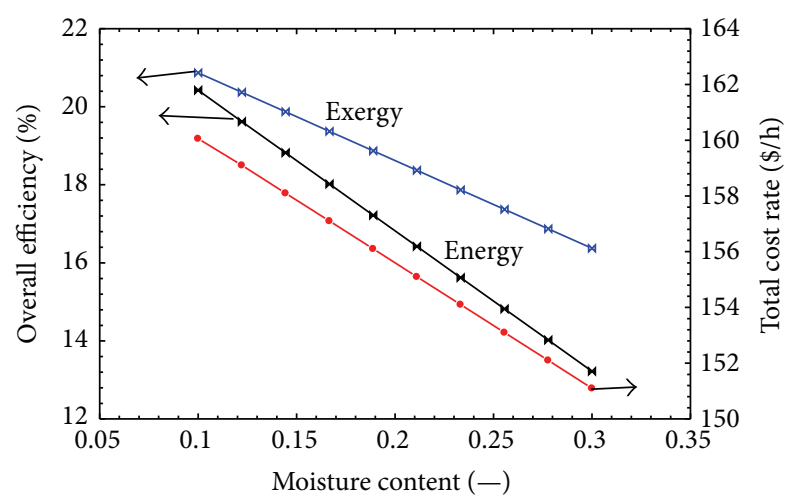

Figure 10: The impact of the biomass moisture content on the objective functions.

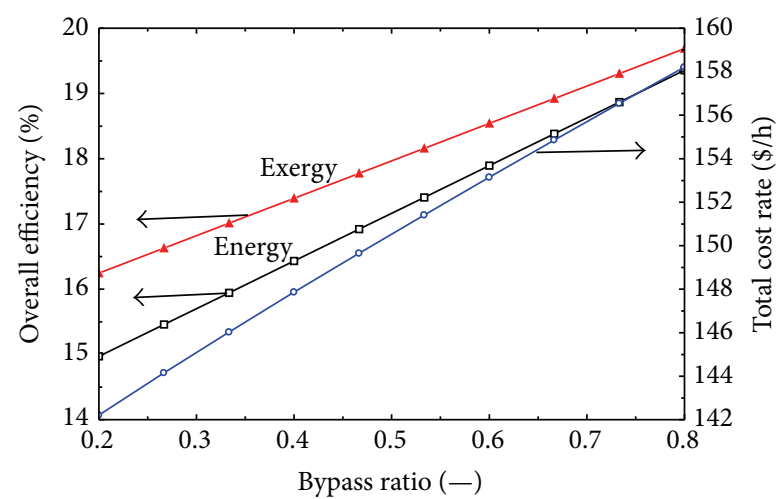

FIGURE 11: The impact of the bypass ration on the objective functions.

energy efficiency, exergy efficiency, and total cost rate of the multigeneration system (Figure 11).

The parametric study of multigeneration system reveals that the design parameters have different effects on the thermodynamic and economic performance of the system. To select the best value of design parameters an optimization method should be done. In the following section the optimization procedure is described.

\section{Optimization Results}

To optimize the performance of the system two objective functions in (28) and (29) are defined. Seven decision variables, namely, gasification temperature, combustion temperature, compressor pressure ratio, moisture content of biomass, temperature inlet to the chiller, bypass ratio, and maximum pressure of ORC, are selected to carry out optimization. Table 5 represents the reasonable range of decision variables.

In this study the genetic optimization option of EES is used to find the optimized value of problem. Genetic algorithm as a repetitive algorithm with random search strategy and biological evolution modeling attempts to find optimal solutions. Exergy efficiency and total cost rate are selected separately as two objective functions. The result of optimization is presented in Table 6 .
TABLE 5: Reasonable range of decision variables.

\begin{tabular}{lcc}
\hline Decision variables & Lower bound & Upper bound \\
\hline Gasification temperature $(\mathrm{K})$ & 950 & 1150 \\
Combustion temperature $(\mathrm{K})$ & 1300 & 1400 \\
Compressor pressure ratio $(-)$ & 7 & 11 \\
Moisture content of biomass $(-)$ & 0.1 & 0.6 \\
Temperature inlet to the chiller $(\mathrm{K})$ & 383 & 460 \\
Bypass ratio (-) & 0.2 & 0.8 \\
Maximum pressure of ORC $(\mathrm{kPa})$ & 800 & 1200 \\
\hline
\end{tabular}

The result of optimization indicates that the exergy efficiency of the system can increase to $21.89 \%$ and total cost rate of the system can reduce to $145.1 \$ / \mathrm{h}$.

\section{Conclusion}

Biomass is clean and available and is a type of renewable energy source that is derived from biomass resources. Biomass energy can be used for direct combustion or gasification process. Accurate modeling of biomass gasification is highly important due to the complex reactions of the gasification process. In this study a multigeneration system integrated with biomass gasifier unit is investigated. A parametric study and a single objective optimization are carried out. The result of parametric study for seven decision variables is presented. The optimization results reveal that the exergy efficiency of the multigeneration system increases about $2.29 \%$ and total cost rate of system can decrease $13.1 \$ / \mathrm{h}$ compared to the initial state of the system.

\section{Nomenclature}

\section{$\dot{C}: \quad$ Cost rate $(\$ / \mathrm{h})$}

DHW: Domestic hot water heater

ex: $\quad$ Exergy $(\mathrm{kJ} / \mathrm{kg})$

HHV: Higher heating value $(\mathrm{kJ} / \mathrm{kg})$

LHV: Lower heating value $(\mathrm{kJ} / \mathrm{kg})$

$m$ : $\quad$ Number of moles required for firing per

kmol of wood

in: $\quad$ Mass flow rate $(\mathrm{kg} / \mathrm{s})$

ORC: Organic Rankine Cycle

$r_{p}: \quad$ Pressure ratio

T: $\quad$ Temperature

$w$ : Amount of water per kmol of biomass

$Z$ : $\quad$ Cost of component.

\section{Subscripts}

AP: $\quad$ Air preheater

C: Carbon

CC: $\quad$ Combustion chamber

ch: Chemical

comb: Combustion

comp: Compressor

Cond,R: Organic condenser

Eva,R: Organic evaporator 
TABLE 6: Optimization results of multigeneration system.

\begin{tabular}{|c|c|c|c|c|c|c|c|c|c|}
\hline & $\begin{array}{c}T_{\text {gasif }} \\
(\mathrm{K})\end{array}$ & $\begin{array}{l}r_{\mathrm{ac}} \\
(-)\end{array}$ & $\begin{array}{c}P_{2 \mathrm{R}} \\
(\mathrm{kPa})\end{array}$ & $\begin{array}{c}x_{\text {bypass }} \\
(-)\end{array}$ & $\begin{array}{l}\mathrm{MC} \\
(-)\end{array}$ & $\begin{array}{c}T_{\text {comb }} \\
(\mathrm{K})\end{array}$ & $\begin{array}{c}T_{\text {inlet,chiller }} \\
(\mathrm{K})\end{array}$ & $\begin{array}{l}\text { Exergy eff. } \\
(\%)\end{array}$ & $\begin{array}{l}\text { Total cost } \\
\text { rate }(\$ / \mathrm{h})\end{array}$ \\
\hline & \multicolumn{9}{|c|}{ Exergy efficiency as objective function } \\
\hline Design & 1100 & 9 & 1000 & 0.8 & 0.6 & 1400 & 400 & 19.6 & 158.2 \\
\hline Optimum & 1050 & 8.99 & 1125 & 0.54 & 0.1 & 1362 & 412 & 21.89 & 154.4 \\
\hline \multirow[t]{2}{*}{ Variation } & -4.55 & -0.11 & 12.5 & -32.5 & -83.3 & -2.71 & 3 & 11.68 & -2.4 \\
\hline & \multicolumn{9}{|c|}{ Total cost rate as objective function } \\
\hline Optimum & 1100 & 9 & 1125 & 0.44 & 0.3 & 1325 & 430 & 15.3 & 145.1 \\
\hline Variation & 0 & 0 & 12.5 & -45 & -50 & -5.4 & 7.5 & -21.9 & -8.3 \\
\hline
\end{tabular}

$\begin{array}{ll}f: & \text { Formation } \\ \text { gasif: } & \text { Gasification } \\ \text { GT: } & \text { Gas turbine } \\ h: & \text { Enthalpy }(\mathrm{kJ} / \mathrm{kg}) \\ K: & \text { Equilibrium constant } \\ \text { ph: } & \text { Physical } \\ \text { Prod: } & \text { Product } \\ \text { Pump,R: } & \text { Organic pump } \\ \bar{R}: & \text { Universal gas constant }(\mathrm{kJ} / \mathrm{kg} \cdot \mathrm{K}) \\ \text { Tur,R: } & \text { Organic turbine } \\ \circ: & \text { Reference state. }\end{array}$

Greek Symbols

$\beta$ : Biomass exergy coefficient

$\psi$ : Exergy efficiency.

\section{Conflict of Interests}

The authors declare that there is no conflict of interests regarding the publication of this paper.

\section{Acknowledgment}

The authors would like to thank National Iranian Gas Company (NIGC) for the helpful support.

\section{References}

[1] H. Li, R. Nalim, and P.-A. Haldi, "Thermal-economic optimization of a distributed multi-generation energy system-a case study of Beijing," Applied Thermal Engineering, vol. 26, no. 7, pp. 709-719, 2006.

[2] F. A. Al-Sulaiman, I. Dincer, and F. Hamdullahpur, "Energy and exergy analyses of a biomass trigeneration system using an organic Rankine cycle," Energy, vol. 45, no. 1, pp. 975-985, 2012.

[3] G. Chicco and P. Mancarella, "A unified model for energy and environmental performance assessment of natural gas-fueled poly-generation systems," Energy Conversion and Management, vol. 49, no. 8, pp. 2069-2077, 2008.

[4] Y. Huang, Y. D. Wang, S. Rezvani et al., "A techno-economic assessment of biomass fuelled trigeneration system integrated with organic Rankine cycle," Applied Thermal Engineering, vol. 53, no. 2, pp. 325-331, 2013.
[5] C. Rubio-Maya, J. Uche-Marcuello, A. Martínez-Gracia, and A. A. Bayod-Rújula, "Design optimization of a polygeneration plant fuelled by natural gas and renewable energy sources," Applied Energy, vol. 88, no. 2, pp. 449-457, 2011.

[6] M. Hosseini, I. Dincer, P. Ahmadi, H. B. Avval, and M. Ziaasharhagh, "Thermodynamic modelling of an integrated solid oxide fuel cell and micro gas turbine system for desalination purposes," International Journal of Energy Research, vol. 37, no. 5, pp. 426-434, 2013.

[7] Y. Huang, Y. D. Wang, S. Rezvani, D. R. McIlveen-Wright, M. Anderson, and N. J. Hewitt, "Biomass fuelled trigeneration system in selected buildings," Energy Conversion and Management, vol. 52, no. 6, pp. 2448-2454, 2011.

[8] S. Khanmohammadi, K. Atashkari, and R. Kouhikamali, "Exergoeconomic multi-objective optimization of an externally fired gas turbine integrated with a biomass gasifier," Applied Thermal Engineering, vol. 91, pp. 848-859, 2015.

[9] M. R. Meigounpoory, P. Ahmadi, A. R. Ghaffarizadeh, and S. Khanmohammadi, "Optimization of combined cycle power plant using sequential quadratic programming," in Proceedings of the ASME Heat Transfer Summer Conference Collocated with the Fluids Engineering, Energy Sustainability, and 3rd Energy Nanotechnology Conferences, pp. 109-114, American Society of Mechanical Engineers, Jacksonville, Fla, USA, August 2008.

[10] T. H. Jayah, L. Aye, R. J. Fuller, and D. F. Stewart, "Computer simulation of a downdraft wood gasifier for tea drying," Biomass and Bioenergy, vol. 25, no. 4, pp. 459-469, 2003.

[11] S. Jarungthammachote and A. Dutta, "Thermodynamic equilibrium model and second law analysis of a downdraft waste gasifier," Energy, vol. 32, no. 9, pp. 1660-1669, 2007.

[12] Z. A. Zainal, R. Ali, C. H. Lean, and K. N. Seetharamu, "Prediction of performance of a downdraft gasifier using equilibrium modeling for different biomass materials," Energy Conversion and Management, vol. 42, no. 12, pp. 1499-1515, 2001.

[13] N. S. Barman, S. Ghosh, and S. De, "Gasification of biomass in a fixed bed downdraft gasifier-a realistic model including tar," Bioresource Technology, vol. 107, pp. 505-511, 2012.

[14] C. Higman and M. Van der Burgt, Gasification, Gulf Professional Publishing, 2011.

[15] S. A. Channiwala and P. P. Parikh, "A unified correlation for estimating HHV of solid, liquid and gaseous fuels," Fuel, vol. 81, no. 8, pp. 1051-1063, 2002.

[16] S. Khanmohammadi, K. Atashkari, and R. Kouhikamali, "Performance assessment and multi-objective optimization of a trrigeneration system with a modified biomass gasification model," Modares Mechanical Engineering, vol. 15, no. 9, pp. 209222, 2015. 
[17] S. Ozlu, Development and Analysis of Solar Energy Based Multigeneration Systems, University of Ontario Institute of Technology, 2015.

[18] P. Ahmadi, I. Dincer, and M. A. Rosen, "Energy and exergy analyses of hydrogen production via solar-boosted ocean thermal energy conversion and PEM electrolysis," International Journal of Hydrogen Energy, vol. 38, no. 4, pp. 1795-1805, 2013.

[19] S. Soltani, S. M. S. Mahmoudi, M. Yari, T. Morosuk, M. A. Rosen, and V. Zare, "A comparative exergoeconomic analysis of two biomass and co-firing combined power plants," Energy Conversion and Management, vol. 76, pp. 83-91, 2013.

[20] P. Basu, Biomass Gasification and Pyrolysis: Practical Design and Theory, Academic Press, 2010.

[21] H. Ganjehsarabi, A. Gungor, and I. Dincer, "Exergoeconomic evaluation of a geothermal power plant," International Journal of Exergy, vol. 14, no. 3, pp. 303-319, 2014.

[22] A. Bejan and M. J. Moran, Thermal Design and Optimization, John Wiley \& Sons, 1996.

[23] P. Ahmadi, Modeling, Analysis and Optimization of Integrated Energy Systems for Multigeneration Purposes, Faculty of Engineering and Applied Science, University of Ontario Institute of Technology, 2013.

[24] S. Soltani, S. M. S. Mahmoudi, M. Yari, and M. A. Rosen, "Thermodynamic analyses of a biomass integrated fired combined cycle," Applied Thermal Engineering, vol. 59, no. 1-2, pp. 60-68, 2013. 


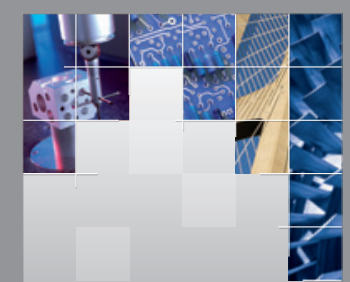

\section{Enfincering}
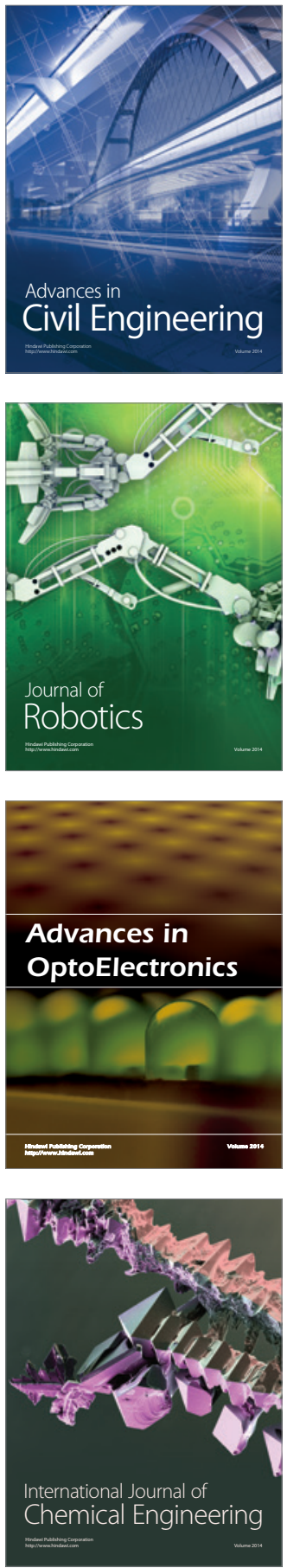

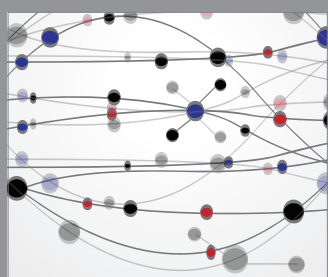

The Scientific World Journal

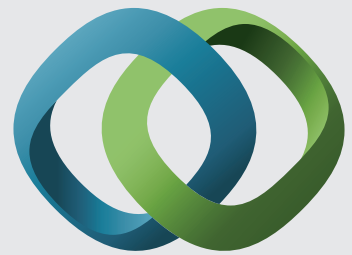

\section{Hindawi}

Submit your manuscripts at

http://www.hindawi.com
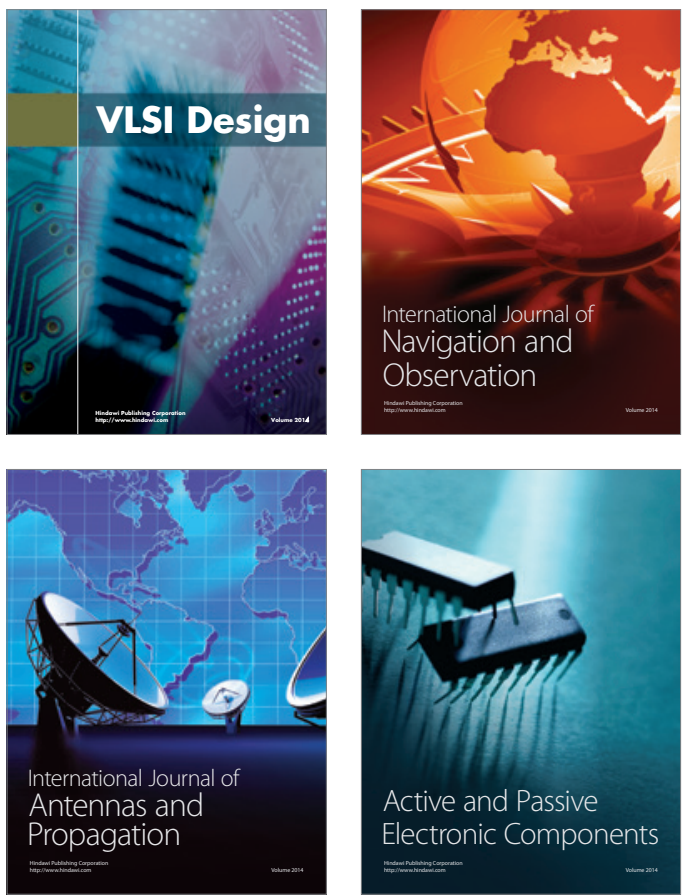
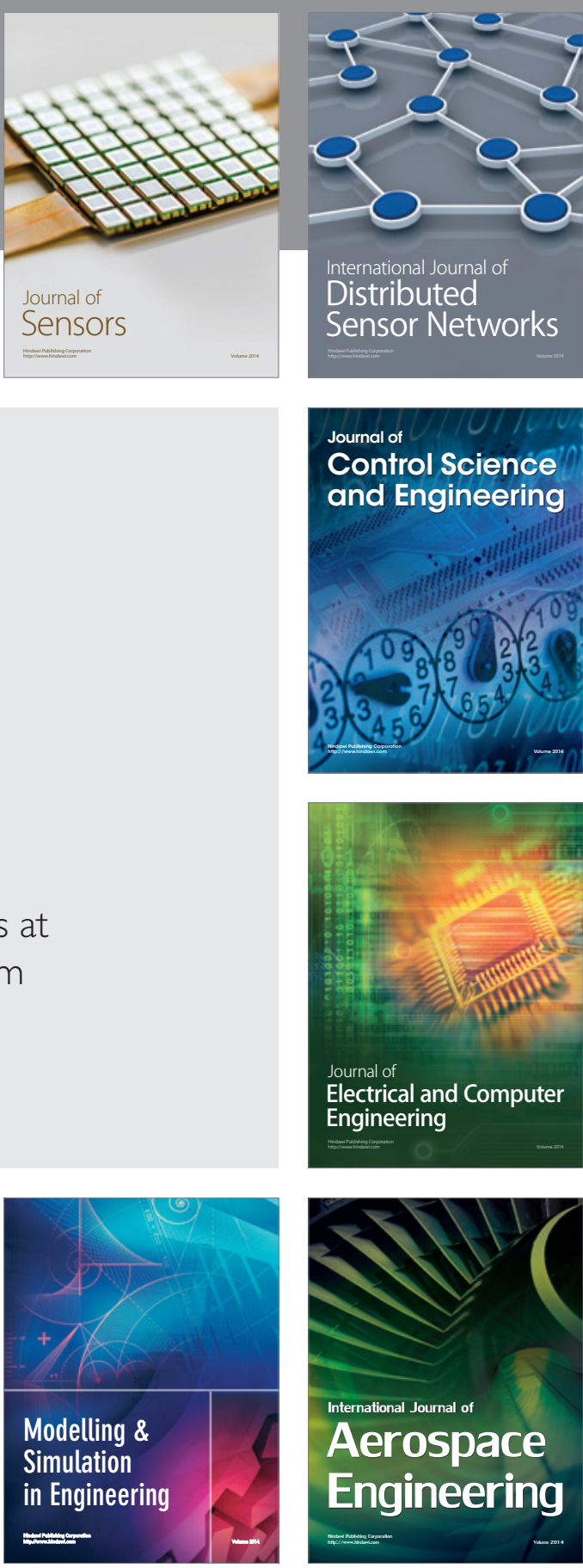

International Journal of

Distributed

Sensor Networks

Journal of

Control Science

and Engineering
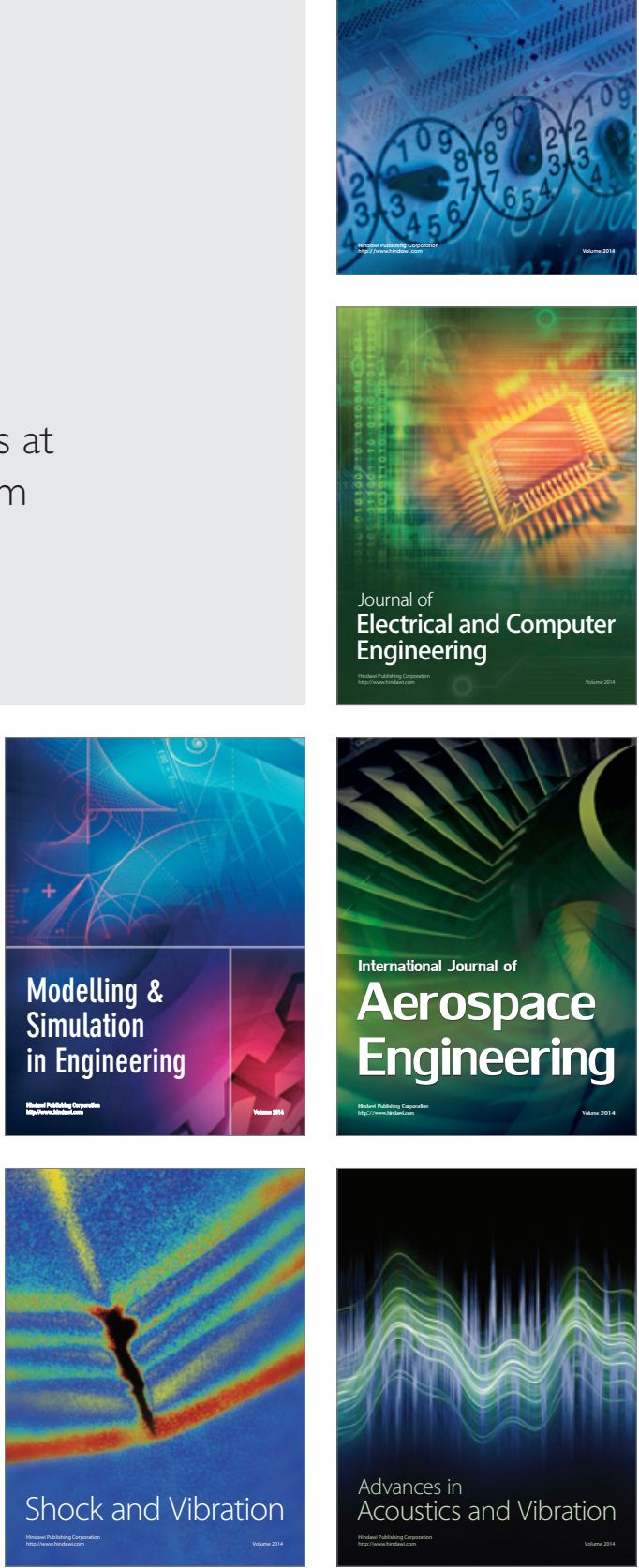